\title{
Counseling Service with A Person Centered Approach to Improve Positive Self-Concept of Students
}

\author{
Emma Lusiana* \\ Postgraduate of Guidance And Counseling \\ Universitas Negeri Yogyakarta \\ Yogyakarta, Indonesia \\ emaa.lusiana9@gmail.com*
}

\author{
Agus Basuki \\ Guidance and Counseling Department \\ Universitas Negeri Yogyakarta \\ Yogyakarta, Indonesia \\ agus_basuki@uny.ac.id
}

\begin{abstract}
Guidance and counseling services are efforts that are used in facilitating students in increasing their potential and helping to overcome students' problems, one of which is about self-concept. The self-concept is a view of self that includes physical dimensions, personal characteristics, and selfmotivation that will have an impact on one's behavior. This study aims to determine counseling services using a personcentered approach can improve student self-concept. This research is an Action Research in Counseling study conducted in two cycles. Data collected using scale, interview, and observation. The participation of this study were 3 high school students who had low positive self-concepts. Data were analyzed descriptively by comparing the percentage achieved before and after counseling was held. The results showed an increase in positive self-concept in students. This is evidenced by the increase in the average score of pre-test, post-test 1 and post-test 2 of the three subjects, namely pre-test at $61.34 \%$ (low category), post-test 1 by $75.28 \%$ (medium category) and posttest 2 of $210.66 \%$ (high category). The results of this study prove that counseling services with a person-centered approach can improve students' positive self-concept.
\end{abstract}

Keywords-guidance and counseling services, person-centered, self concepts, action research

\section{INTRODUCTION}

The self-concept is the most important concept of one's personality, where the concept of self is a view, and values that include awareness about self [1]. The concept of self as the core of personality has an important or key role in determining what concepts are acceptable for assimilation into the organization of the whole personality [2].

A person's self-concept will determine how that person behaves if someone who has a negative self-concept has a tendency to be hampered in the process of development and unable to carry out developmental tasks properly but if he has a positive self-concept towards himself will support positive behavior. The self-concept has two basic functions namely being able to organize experiential data, specifically experiences involving social interactions, into predictable sequences of actions and reactions. Second, self-concept facilitates efforts to meet the need to avoid disapproval and anxiety [2]. Someone with a positive self-concept has the characteristics of a) confident of one's potential, b) feeling equal to others, c) receiving compliments without shame, d) being aware of diversity, e) being able to develop themselves [3].

When students have a negative view of themselves, a negative understanding will be hampered in its development so that in helping to improve positive self-concepts in students in the counselor education unit can help by providing counseling services and using utilizing approaches in guidance and counseling.

Guidance and Counseling Services is an effort to assist by teacher guidance and counseling for students in understanding themselves, the surrounding environment. Besides, guidance and counseling services also help students in overcoming their various problems experience. Counseling is used as an effort to reduce difficulties, overcome various crises, and improve welfare in his life by helping students become creative, innovative, and independent in making decisions [4]. Counseling utilizes various approaches and techniques.

Guidance and counseling services in schools is a process that utilizes various techniques carried out by guidance and counseling teachers to assist students in overcoming problems that are being experienced so that they can develop fully in the community [5]. One approach in guidance and counseling that can help improve self-concept is the person-centered approach. The person-centered aims to help the counselee find a more positive self-concept through counseling communication, the counselor places the counselee as a valuable person, important person, and people who have positive potential with unconditional positive acceptance, which is to accept the counselee as he is [6].

Person-centered is one approach in guidance and counseling that can be used in the individual counseling process to solve students' problems. A Person-Centered Approach is a client-focused approach. Counseling services with a person-centered approach is a method of psychological treatment that is carried out by way of dialogue between counselor and counselee, to achieve a harmonious picture between the ideal self and actual self [7]. The aim is to help the counselee in their growth process so that the counselee can get better overcome the problem because they can identify themselves [8]. 
The focus of person-centered therapy lies in understanding students as counselees in terms of understanding all the uniqueness that exists in him from time-to-time [4, 9]. Person-centered places great emphasis on the relationship between the therapist and his client. The core condition of the therapist is congruence, unconditional positive regard, and accurate emphatic understanding and then many school counselors have applied it as an important thing in their task to facilitate changes in the therapeutic process [9].

Three therapeutic conditions such as congruence, unconditional positive regard, and accurate emphatic understanding are given in the counseling process and without directional intervention will produce significant results [10]. This study is to see whether an effective personcentered approach is used in enhancing students' positive self-concepts.

\section{METHODS}

This research uses action research in counseling. Guidance and counseling action research is defined as a form of reflection study by the action taker, which is carried out to improve the rational stability of the actions in carrying out the task, deepen the understanding of the actions taken, and improve the conditions under which counseling practices are carried out [11]. The subjects in this study were 3 students who had low positive self-concepts. This type of data collection uses a Likert scale, interviews, and observations. The data analysis technique used in this study uses quantitative analysis and qualitative analysis. Data were analyzed descriptively by comparing the percentage achieved before and after counseling was held.

\section{RESULT AND DISCUSSION}

Result

This research was conducted on three students who have low positive self-concepts by providing counseling services through a person-centered approach. This research applies two cycles. Before being given action, the researcher conducted data collection by giving a self-concept scale of 25 three students who had low scores when viewed from the self-concept categories that were determined by the researchers in Table.1.

Table 1. Self-Concept Criteria

\begin{tabular}{|c|c|}
\hline Score Range & Level of Self-Concept \\
\hline$>209$ & High \\
\hline $133-209$ & Medium \\
\hline$<133$ & Low \\
\hline
\end{tabular}

The results of the students' self-concept scale identified three students who had low positive self-concepts based on the criteria above presented in the Table. 2 :

Table 2. Results of The Self Concept Scale

\begin{tabular}{|l|l|l|l|}
\hline No & Initial Name & \multicolumn{1}{|c|}{ Score } & Criteria \\
\hline 1 & AW & 129 & Low \\
\hline 2 & UU & 128 & Low \\
\hline 3 & FR & 131 & Low \\
\hline
\end{tabular}

In addition to using the scale of self-concept in collecting data, researchers also use interviews and direct observations in which of the three subjects obtained behavior that describes low positive self-concept such as: there is confidence in himself always considers himself stupid, inferior when dealing with people who feel more from him, feeling inferior, and difficult to adapt to the new environment because of lack of confidence in him.

\section{Discussion}

After obtaining data about students who have a low positive self-concept. The researcher immediately provides action by conducting individual counseling using personcentered.

The first cycle is given by conducting individual counseling with each student. The first stage of counseling is to create a warm, free and permissive situation by building rapport with counselee that aims to make the counselee feel comfortable. After creating a good relationship the next step is to explore the client's problems where the client is welcome to explain freely and openly about the problems they are experiencing. Then the next stage is an in-depth interview about the client's problem. The role of the counselor in this counseling process is as a facilitator for the counselee to understand himself. The counselor shows congruence, unconditional positive regard, and accurate emphatic understanding during the counseling process. That way clients can realize themselves and can make their own choices.

After the first cycle is complete, the researcher conducts a post-test 1 to determine the level of self-concept after an action is taken. The results of the post-test 1 were used as a reference to carry out cycle 2 of the post-test 1 data used as evaluation material. Following are the results of the post-test 1 obtained by the data:

Table 3. Post-Test Results 1

\begin{tabular}{|l|l|l|l|}
\hline No & Initial Name & \multicolumn{1}{|c|}{ Score } & Criteria \\
\hline 1 & AW & 170 & Medium \\
\hline 2 & UU & 165 & Medium \\
\hline 3 & FR & 180 & Medium \\
\hline
\end{tabular}

Based on the results of post-test 1 , it can be concluded that the results obtained have increased, but not by the indicators of success that is by increasing high positive selfconcept. Then the researchers conducted a second cycle with the same technique. The counselee stage starts from creating a warm, free and permissive situation by building rapport with the counselee that aims to make the counselee comfortable. After doing the rapport, the counselor reviews the matters in the first cycle again. In the counseling process, the counselor displays a genuine attitude, empathy and always accepting the counselee unconditionally.

In this second cycle, the client is expected to be able to make decisions that will support the improvement of his concept. The counselor invites the counselee to look at himself from a positive side and make a decision to fight things that consider him weak by exploring the positive things that exist in the counselee.

After the second cycle is complete, the researcher returns to taking post-test 2 , the data of which is used to determine the level of self-concept after the two cycles are 
carried out. The results of the post-test 2 were used as research results because post-test 2 was the final measurement. Following are the results of the post-test 2 in table 4:

Table 4. Post-Test Results 2

\begin{tabular}{|l|l|l|l|}
\hline No & Initial Name & \multicolumn{1}{c|}{ Score } & Criteria \\
\hline 1 & AW & 210 & High \\
\hline 2 & UU & 209 & High \\
\hline 3 & FR & 220 & High \\
\hline
\end{tabular}

An increase in positive self-concept scores is elaborated in the results of data processing and scale data as follows :

Table 5. Results Of An Increase In Positive Self-Concept Scores

\begin{tabular}{|l|l|l|l|l|}
\hline No & $\begin{array}{l}\text { Initial } \\
\text { Name }\end{array}$ & Pre-test & Post-test 1 & $\begin{array}{l}\text { Post- tests } \\
\mathbf{2}\end{array}$ \\
\hline 1 & AW & 129 & 170 & 210 \\
\hline 2 & UU & 128 & 165 & 209 \\
\hline 3 & FR & 131 & 180 & 220 \\
\hline Amount & 388 & 515 & 639 \\
\hline Percentage(\%) & 61.34 & 75.28 & 92.29 \\
\hline Average & 129.33 & 171.66 & 210.66 \\
\hline Category & Low & Medium & High \\
\hline
\end{tabular}

After analyzing scores from before being given action, then cycle 1 and up to cycle 2 , it can be concluded through the improvement graph below. It appears that there was an increase after the administration of action.

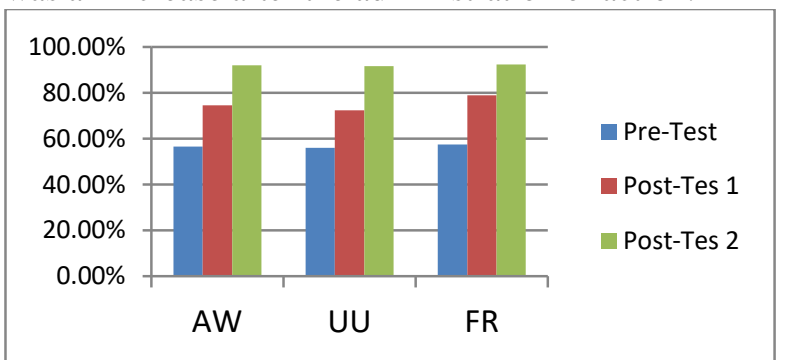

Fig. 1. Graph Of Increasing The Subject's Positive Self-Concept

\section{CONCLUSION}

Based on the results of research and discussion, it is concluded that positive self-concept can be improved by using counseling services with a person-centered approach. This can be seen from the comparison of the average results between pre-test and post-test that have increased after taking action. The average score of self-concept in the pretest was $61.34 \%$ (low category), post-test 1 was $75.28 \%$ (medium category) and post-test 2 was $210.66 \%$ (high category). Also, researchers evaluated the three subjects by interviewing subject teachers to determine changes in behavior, then the researchers conducted direct observations that obtained data after counseling using a person-centered approach. The three subjects experienced an increase in positive self-concept.

\section{ACKNOWLEDGMENT}

The researcher would like to thank all those involved in this research, who provided insights and expertise that were very helpful in research. Hopefully, this research can be useful for readers and scientific development, especially in the field of guidance and counseling. I also don't forget to thank the Postgraduate Guidance and Counseling study program at Yogyakarta State University.

\section{REFERENCES}

[1] Thalib, S.B. "Psikologi Pendidikan Berbasis Analisis Empiris Aplikatif”. Jakarta: Kencana Prenada Media Grup. 2010.

[2] Epstein, S. The self-concept revisited: Or a theory of a theory. American Psychologist, Vol. 28(5), Hlm. 404-416. 1973.

[3] Rakhmat, Jalaludin."Psikologi Komunikasi”. Bandung: Remaja Rosdakarya 2005

[4] Ojo Olugbenga D. "Multimodal counselling therapy: strategy for learner support in distance learning". Malaysian journal of distance education. Vol. 2(2), hlm. 1-13 . 2010.

[5] ND Oye, MC Obi, TN Mohd, and Bernice, A. "Guidance and counseling in nigerian secondary schools: the role of ict". I.J.Modern Education and Computer Science. Vol.8, hlm. 26-33. August 2012.

[6] Komalasari, G.,Wahyuni, E., Gantina. "Teori dan Teknik Konseling”. Jakarta: Indeks. 2011.

[7] Willis, S. Konseling Individual teori dan Praktek. Bandung: Alfabeta. 2004

[8] Corey , Gerald. "theory and practice of counseling and psychotherapy" USA: Brooks/Cole. Hlm.172-209. 2013.

[9] Cooper, M., \& McLeod, J. "Person-centered therapy: A pluralistic perspective". Person-Centered \& Experiential Psychotherapies. Vol.10(3), Hlm. 210-223. September 2011.

[10] Quinn, A. "A Person-Centered Approach to Multicultural Counseling Competence”. Journal of Humanistic Psychology. Vol. 53(2). Hlm. 202-251. 2012.

[11] Sudarti, Kris. "Peningkatan Motivasi Belajar Siswa Melalui Bimbingan Kelompok". Jurnal Prakarsa Paedagogia. Vol. 1 (1). Hlm. 14-23.. Juni 2018. 